International Journal of Scholarly Papers for Media and Communications

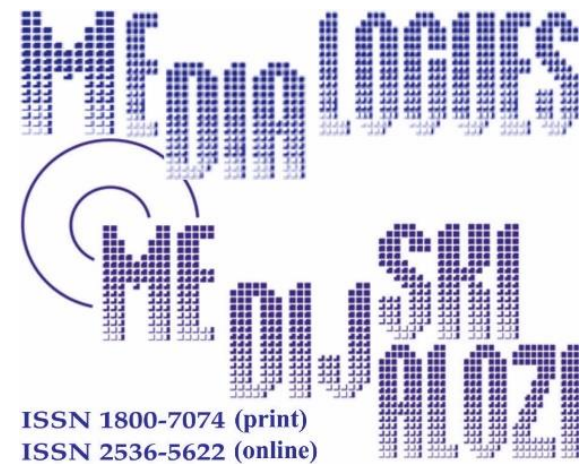

Delibasic, M., Jovovic, R., Draskovic, V., Grabowska, M. (2021), „Media Economics and Killing Boredom”, Media Dialogues / Medijski dijalozi, Vol. 14, No. 4, pp. 73-82.

\title{
Media Economics and Killing Boredom
}

\author{
Assistant professor MILICA DELIBASIC,
}

Mediterranean University, Faculty of Business Studies, Podgorica, Montenegro

Professor RADISLAV JOVOVIC, Mediterranean University, Faculty of Business Studies, Podgorica, Montenegro

\section{Professor VESELIN DRASKOVIC,}

University of Montenegro, Maritime faculty Kotor, Kotor, Montenegro

\section{Associate Professor MONIKA GRABOWSKA}

Wroclaw University of Economics,

Wroclaw, Poland

\begin{tabular}{|c|c|}
\hline $\begin{array}{l}A R T I C L E \\
\quad I N F O\end{array}$ & $\begin{array}{cl}\text { Received: December 02, } 2020 & / \text { Revised from: January 02, } 2021 \\
\text { Accepted: February 04, } 2021 & / \text { Available online: July 15, } 2021\end{array}$ \\
\hline$D O I$ & doi.org/10.14254/1800-7074/14-4/6 \\
\hline
\end{tabular}




\begin{abstract}
The paper elaborates the idea that media economics is essentially based on accomplishing the economic aspects of killing boredom among the widest audience. The subject of research is the economic and management reactions of the media industry to exponential changes. The aim of the research is to explain the possibility of creating a specific media culture by forcing and imposing certain global ideological-interest matrices (e.g. neoliberal), consumerist, individualistic, and other. The paper uses general methods of social sciences. The starting point is the hypothesis that the vast majority of media are dependent, because they are essentially based on the launch and realization of their owner's interests. The main result and conclusion of the research is the indisputable fact that some dominant ideas (recipes) of the West (even if they were wrong, as is the case of economic neoliberalism) are orchestrated and propagated in the mass media, which is socially harmful.
\end{abstract}

KEYWORDS: Media industry, mass media, media psychology, media dependence, new media, communications.

\author{
"People do what they are paid to do, \\ and act in accordance with their own motives. \\ However, from a social point of view, \\ in many cases they are paid \\ to do something wrong". \\ Luis Garicano
}

\title{
INTRODUCTION
}

People work so they can rest, and they rest so they can work. People use a variety of media both during work and during rest. Huge amounts of money are spent on media content and its use (information and communication technologies - ICT). In developed countries, the media industry (as a sum of several industries) participates with approximately $3 \%$ in the national income, and the rate of its economic growth has been significantly higher than the rate of total economic growth in the last three and a half decades. It seems that this is mainly related to the increase of free time, great growth of the advertising market, demographic and technological changes, strengthening of the globalization process, audiovisual communication boom, significant development of media infrastructure and convergence of information oversaturated media markets with previously isolated telecommunication markets, computers, home electronics, and software (Draskovic et al., 2017, p. 7).

The development of media industry is directly related to the development of the so-called post-industrial society (see more in: Draskovic et al., 2010; V. Draskovic, 
et al., 2013) and within it the tertiary sector of the economy. In this sense, one must keep in mind the statement of D. Bell $(1967 ; 1973)$ that "the concept of post-industrial society is only an analytical construction, not a picture of a specific and concrete society... a paradigm, a social scheme, which sets new coordinates of social organization in modern Western society." Thereby, it is understood that post-industrial society, like any new historical period, requires a paradigmatic change in the way of thinking and behaving, which in principle comes down to adapting to civilization norms, achievements, and challenges (Draskovic, 2002, p. 11).

This manuscript explains the relationship between extremely important topics present in everyday life and work, such as media and management, especially from the aspect of the importance and role of information and management techniques. Information is a binding and common element of media and management, and management techniques are a necessary tool in the business of all media organizations. Media and management are integral parts of our everyday lives. Our lives and business activities cannot be imagined without them. Today, it seems that only imagination is their limit, which means that they practically have no limit. Nevertheless, the limits of applying management in the media are determined by the much broader social (especially political) context of media specifics.

The essence of the relationship between the four types of the modern world: media, political, economic and social, is also being phenomenologically considered. The starting point is the hypothesis that profit motivation in the first three worlds leads to crisis and poverty in the fourth world (society). Furthermore, intensive and programmed exchange of information is enabled by continuous improvement of media technologies. It is subordinated to rent-oriented values of the media, corporate, and political order. Finally, the bare economic logic of profit in the first three worlds relativizes the importance of public interests and the weak democratic and creative potential of society as a fourth world.

We also tried to consider selectively chosen motives, facts, hypotheses, specific questions, and dilemmas, which represent important inserts, but not a complete story about the media as a breaking mirror of globalization, which is often presented as an overture to the so-called ,new world order" (which some interpret as the sum of various forms of ,new imperialism"). Our goal is to point out the need for a paradigmatic change in the way of thinking and behavior of media management, which in principle should be based, among other things, on adapting to civilization and development norms, achievements and challenges (instead of interest-driven motives).

\section{MEDIA AND CHANGE}

Our modernity is characterized by many specific situations, because exponential changes have literally become a "time and space constant" (Collins \& Devanna, 2002, p. 353). It seems that A. Einstein was right when he metaphorically said: "Life 
is like riding a bicycle. To keep your balance, you must keep moving." It can be noticed that a lot is changing in the field of cultural artifacts as well. Namely, many traditional terms are getting a media prefix: media subjects, media reality, media center, media conference, media sphere, media magazine, media dialogues, etc. However, it does not end there, because even many other modern terms add a media prefix. At the same time, these terms take on a new meaning in modern social, institutional, cultural, political, scientific, and technological (globalized) circumstances.

Obviously, there is a mutual cause-and-effect relationship between media and globalization, because the so-called "new media“ and communication contributed to the acceleration of globalization, which in turn enabled the creation of mega-media.

Media have long played a major role „in the life“ of modern society. Their role is recognized and generally acknowledged in the economic sphere, political debate, and the general cultural process, information service to citizens and the formation of value criteria of the audience. However, we have an impression that the field of media economics has been underestimated in some inexplicable way among our regional researchers. The term ,mass media“ in the last two decades has increasingly referred to mass communications. The role of the press, television, radio, online sources, movies, videos, mobile phones, etc. is huge today. Therefore, modern society is not only called ,informational“, but also „,mediated“, because it largely depends on the media. Essentially, the foregoing testifies to the institutionalization of the notion under consideration.

\section{MEDIA ECONOMICS}

Mass media is the subject of economic analysis for several reasons. The multilayered media industry is a developed and highly profitable sector of the economy, having its own specific economic laws of functioning, both within the media themselves as special systems, and their relations with companies and numerous institutions from the environment. As a separate industry (or a set of various industries), mass media work not only for profit, but also to meet the special needs of the public, and different interests of numerous social groups. Due to all that, media economics (and management as its organizational and management component) is an extremely important socio-economic scientific discipline. It explores the conditions and profitability factors of the considered economy sector. In addition, its importance is emphasized by the fact that media economics analyzes the area of close and complex interactions between the ,three pillars“ on which the prosperity of the media rests: corporate business (advertisers), state (regulator), and society (an audience that pays with their money and dedicates their free time). Finally, the media industry is chan- 
ging the rhythm and dynamics of all people's lives because, among other things, it „kills boredom"1 (metaphorically), at least among individuals (selectively).

The red thread of „media life“ has always been (and remains!) dual: the production of certain values (services, information, attitudes, ideas, performances, etc.) and the "killing" of people's free time (so-called ,, leisure“ or boredom). In order for the media to constantly maintain and develop this red thread through the continuity of the aforementioned dual relationship, it is necessary for all the above-mentioned aspects of media „life" to function simultaneously. We have (intentionally) written this article atypically, in accordance with the belief that atypicality is one of the significant and general characteristics of the media industry. If for no other reason, then due to the undoubted fact that media products in economic terms operate simultaneously, not only in two markets (goods and services), but also in the third market, the so-called „,network goods“.

The relationship between management (as a derived economic discipline) and the media is highly complementary, interdependent, mutually conditioned, and connected by multiple correlations. It can be viewed from various aspects. But it seems to us that one of the most important aspects is success, because it is a common target criterion. Certainly, there are no successful media without quality application of management, nor is it possible to have a successful management that does not use modern media. The primary task of media management is to overcome numerous limitations in the business environment and in the media markets by applying new knowledge, technologies, and information. It is a safe way to ensure the quality and network suitability of the media product (service), and thus the competitive advantages of the media house and the development of its key competencies.

\section{MEDIA DEPENDENCE}

There is an indisputable gap between the rhetoric of media advocacy for some civilization values and practices and the constant stifling of pluralistic institutional changes (as the basis for economic and social development), as well as numerous civilization values. We believe that any functional and well-argued critique of targeted and (often) orchestrated propaganda (and application!) of economic neolibera-

\footnotetext{
${ }^{1}$ This metaphorical expression of ours (syllogism) can be related to Aristotle's belief that happiness is the purpose of life. We believe that killing boredom is part of happiness. S. Freud and A. Schopenhauer also claimed that the best thing people can hope for in life is not to suffer and not to be unhappy. The multiple and multidisciplinary aspects of media are a guarantee that they can serve well for a considered purpose: economic (Picard, 1989; Greco, 1999; McChesney, 1997; Compaine \& Gomery, 2000; V. Inozemtsev, 2000; Albarran, 2002; Doyle, 2002; Picard , 2002; Bartholow, et al., 2003; Bagdikian, 2004; Alexander et al., 2003; Albarran et al., 2006), technological, institutional, and cultural (Adorno \& Horkheimer, 1972, Bozovic, 2016), political and ideological (Althusser, 1971; Gramsci, 1971), information (Balnaves et al., 2001), communication (Smythe, 1977; Mosco, 1996; Nazarov, 2000), globalization (Rutovic, 2010), legal, artistic, apologetic, and other aspects.
} 
lism and neo-imperialism in the media is good. Therefore, we start with the hypothesis that, similar to bad media news, exhibition and experimental neoliberal economic elaborations in the media are extremely dysfunctional. Among other negative consequences, they cause the effect of saturation in the media audience. J. Keane (1995, p. 94) rightly noted the negative role of quasi-neoliberalism in the control of society, emphasizing that "flirting of market liberalism with pseudo-liberalism is a key means to achieve its basic goal: to take control of the present and future, to commercialize communication media and subject them to new forms of state control, redefining and monopolizing the prevailing collective sense of the historical past." Here should be added that instead of state control, control of alternative institutions was formed in most post-socialist states.

The dominant one-sided media manipulation-information model should be replaced by a two-sided equal communication model. Changing information parameters (especially interactivity, multimedia, and teamwork) as the basic categories of modern media and appropriate information content in the transition from media product to convergent content formats, can significantly contribute to the democratization and institutionalization of the media industry. In order to achieve this in practice, it is necessary to transform the media from a means of (secret or semi-public) management of mass information to a means of open mass collaborations (a term proposed by J. Habermas) with a public, generally available status.

The media are a mirror of the existing social and economic reality in which they often exist dependently (i.e. imposed by some subjects). It can be hypothetically noted that even a superficial comparative analysis shows various forms of crisis (social, economic, institutional, moral, managerial, political, ideological, scientific, educational, cultural, and other) more than proportionally negatively reflect on the media, i.e. to a complete matrix of their parametric values (freedom of expression, quality of reporting, staff training, dependence on ruling nomenclatures, apologetics, tabloids, public trust, technological equipment, profitability, etc.).

Media dependence (political, party, economic, and other) is a global and local phe-nomenon, which only manifests and masks differently. Economic dependence in society is predominantly reflected in media dependence. The rapid development of communication and information technologies affects it, regardless of the participation of $70 \%$ (according to International Data Corporation data) of the communication format, which is called content (a product created by Internet users in communication „many-to-many"). Similar to dysfunctionality of media "bad news", poor economic elaboration and monistic (e.g. dirigiste and/or neoliberal) exhibitions also lead to the phenomenon of audience saturation, and to obscuring the essence of economic problems, especially to obscuring the need for urgent pluralistic institutionalization (economic and social). Ignoring pluralistic institutionalization in the media and practice enables (again!) the substitution of the propagated (e.g. transitional) "kingdom of freedom" by mass phenomena of the "kingdom of necessity". 
When almost nothing is produced in the gloomy and crisis social and economic reality, but mostly the so-called "deals", which at the same time bring enormous profits to the rare "builders", while the masses are at loss, then more and more various types of extreme games (money pyramids, bookmakers, reality TV shows, etc.) begin to produce, which also rare individuals win, and many people easily spend (lose) hard-earned money. The reality show can be seen as a long-lasting and developing media phenomenon of „masked prostitution“ (a term by R. Bozovic), in which the boundaries of many components of everyday (perhaps apparent?) reality that we know are often erased. An attempt is made to explain the essence of the reality show as an alternative media product, through the prism of e.g. sadistic spectator satisfaction, abuse of actors, identification of spectators with participants and the like, with the additional motive of entertainment (,It is a consolation to the wretched to have companions in misery" - Pascal) and escape from their own problems. It is not our goal to point out the well-known anti-characteristics of reality shows, in which the winner is usually the biggest anti-hero and anti-role model. We want to hypothetically state the fact that the general and long-lasting crisis (global and local, social and economic, value criteria, moral, etc.) in terms of hyper-technological possibilities, has led to commercially oriented (profit) media production, which to a greater or lesser extent represents a virtual substitute for proclaimed development, freedoms, democracy, competition, better life, etc.

Although the appearance of the so-called ,new media“ occurred in the recent past, almost simultaneously and in parallel with the momentum of globalization, their dizzying development and perspectives (similar to globalization), objectively bring us to a situation that E. Toffler called ,collision with the future“. In the modern global economy, strict and imposed laws and rules of conduct (with geo-political and geo-economic strategies) have no place for altruism and naive idyll. The general and media reality must be viewed as they are: highly interest-oriented and dependent. At the same time, the media are only one of the levers of power, which cannot function successfully without a quality application of management. Lefebvre argued that the command over space is a fundamental source of social power, and Landes supplemented his statement with the power over money and time. Without new media, these authorities are simply not possible, and thus neither social power nor the world (understood in a metaphorical and utopian sense) could be a ,global village“" (the expression of M. McLuhan, who foreshadowed the arrival of a time of communication without prohibitions and obstacles).

The media have become increasingly interesting to study in various scientific disciplines. The rapid and strong development of the media industry at all levels of local, national, regional, and global communication has conditioned the growing importance of the business aspect of the media, primarily the profitability of media entities and their concentration. They seem to dominate over communication aspects of the media (information and communication content). This leads to neglecting the important context of preserving the informational, cultural, political, and social role of 
media communication. No less important is the relationship between profitability and the social role of the media, since the opinion about becoming the so-called "social conflict" between economic profitability and social responsibility of the media. The social role of the media is in a way subordinated to business (e.g. marketing lease of media space) and political aspects.

However, it should be noted that during the last global financial crisis, the media played a constructive role. They found that even private property (banks and corporations) was often covered and hidden by a cloak of special ties to the state. Without going too far into the economic essence of the problem, the media zealously announced and warned for months and years that the situation in the real estate market was overheated and that sooner or later there would be an end to rising prices and uncontrolled credit market heats with over-valued mortgages and stimulating at the cost of capital.

The media culture of the information society has developed in parallel with the new direction of the management system - media management as an important component of the management of socio-cultural activities. It is a comprehensive and complex means of human exploration of the world that surrounds it, i.e. all its aspects: social, intellectual, moral, artistic, psychological, political, economic, institutional, etc. The level of modern mass media development and the specifics of their versatile influence on the personality proves that the media are one of the factors in the practical application of the ,dialogue of cultures" theory. In this sense, the cultural paradigm of the modern information society should be directed at accepting the compromise of civilization conceptions, among other things, at erasing the boundaries between the „mass" and the „elitist“. Computers and telecommunication technologies have the role (function) of instruments for balancing information, political and spiritual expansion and distribution, which creates new social values (but also myths).

Pluralistic social mass communications (as a process of information circulation) function through intermediaries (various forms of media). Through its various mechanisms, the media industry phenomenologically encompasses all areas of social life, and thus has the power of specific (symbolic - Luhmann, 2000) management of society, i.e. it has control over it. Therefore, investigative and independent journalism should strengthen. However, D. McQuail (2008, p. 54) warned that "it can easily become obsolete" if it turns into an ideological diversion (as is often the case). We believe that a developed institutional environment is the most important condition for the development of independent and investigative journalism. On the other hand, it is clear that the so-called "unprincipled coalition" between the media, politics, and business in institutional terms is their biggest obstacle, in addition to nontransparency (unavailability and/or privilege) of information. 


\section{CONCLUSION}

We live in a great institutional vacuum, which has created an extremely growing and illegally affirmed individualism (forced quasi-neoliberalism, etc.). The development of media industry requires not only an increase in knowledge, motivation, commitment, and will of journalists to overcome complex, crisis and often destructive institutional and business fragmentation. It is a condition for a more independent and better explanation of the essence and meaning of many modern changes, problems, and phenomena. However, for the development of media culture and media pluralism, it is necessary to overcome all dogmatic and quasi-institutional monisms (which include quasi-neoliberalism), which have a totalitarian character.

Any orientation towards narrow (anti-mass and anti-institutional) individual, political, party, ideological, and any other high-interest media indoctrination, favouritism and privilege are archaic, socially harmful, and dangerous. Cross-cultural and cross-institutional bridges are built very slowly, but they are completed sooner or later. Their ceremonial opening happens from time to time and reveals a conglomeration of social pathology, which has long and (un)skillfully hid under the programmed layers of media apologetics, professional and ideological dependence. This pathology is characterized by a high degree of unprofessionalism, tabloidization, ideologization, dogmatization, irresponsibility, imitation, improvisation, and dependence on various power centers.

\section{REFERENCES}

Adorno, T., Horkheimer, V. (1972), "The Culture Industry: Enlightenment as Mass Deception" in The Dialectics of Enlightenment, Heder and Heder, New York.

Albarran, A. B. (2002), Media Economics: Understanding Markets, Industries, and Concepts, 2nd. ed., Ames Iowe State University Press, Blackwell, IA.

Albarran, A. B., Chan-Olmsted, S. M., Wirth, M. O. Eds. (2006), Handbook of Media Economics. Lawrence Erlbaum Associates, Mahwah, New Jork.

Alexander, A., Owers, J., Carveth, R., Hollifield, C.A., Greco, A.N. Eds. (2003), Media Economics: Theory and Practice, 3rd ed., Lawrence Erlbaum Associates, Mahwah, New Jork.

Althusser, L. (1971), "Ideology and Ideological State Apparatuses" in Lenin and Philosophy and other Essays, New Left Books, London, pp. 121-176.

Bagdikian, B. H. (2004), The New Media Monopoly, Beacon Press, Boston, Ma.

Balnaves, M., Donald, J., Donald, S. (2001), The Penguin Atlas of Media and Information. Key Issues and Global Trends. Penguin Reference, New York.

Bartholow, B. D., Dill, K. E., Anderson, K. B., Lindsay, J. J. (2003), „The Economics of Media Violence" in I. E. Sigel (Series Ed.) \& D. A. Gentile (Vol. Ed.), Advances in Applied Developmental Psychology: Media Violence and Children, Greenwood Publishing, Westport, CT. 
Bell, D. (1967), "Notes on the Post-Industrial Society", The public Interest, No. 7, pp. 102-118.

Bell. D. (1973), The Coming of Post-Industrial Society: A Venture in Social Forecasting, Basic Books, New York.

Bozovic, R. (2016), Prayer of Solitude, Cigoja Press, Beograd (in Serbian).

Collins, E., Devanna, M. A. (2002), Challenges of management in the 21 century, Mate, Zagreb (in Croatian).

Compaine, B.M., Gomery, D. (2000), Who Owns the Media: Competition and Concentration in the Mass Media Industry, Lawrence Erlbaum Associates, Mahwah, New Jork.

Doyle, G. (2002), Understanding Media Economics, SAGE Publications, London.

Draskovic, V. (2002), Contrasts of Globalization, Economics and Faculty of Maritime Studies, Belgrade-Kotor (in Serbian).

Draskovic, V. et al. (2010), Globalization in the Mirror of Development, Crisis and Media, Elit, Podgorica (in Serbian).

Drašković, V., Jovović, R., Drašković, M. (2013), Paradigmatic Knowledge, ELIT and Faculty of Maritime Studies, Podgorica and Kotor.

Draskovic, V., Jovovic, R., Delibasic, M. (2017), Media Life - Economic Aspects Killing Boredom, Elit, Podgorica (in Serbian)

Gramsci, A. (1971), Selections from the Prison Notebooks, International Publishers.

Greco, A.N. ed. (1999), The Media and Entertainment Industries: Readings in Mass Communications, Allyn \& Bacon, Boston, MA.

Inozemtsev, V. (2000), "Paradoxes of post-industrial economy", World economy and international relations, No. 3, ss. 3-11 (in Russian).

Kin, J. (1995), Media and democracy, Filip Višnjić, Belgrade (in Serbian).

Luhmann, N. (2000), The Reality of the Mass Media, Stanford University Press. Stanford,

McChesney, R.W. (1997), Corporate Media and the Threat to Democracy (Open Media Pamphlet Series), Open Media, New York.

McQuail, D. (2000), McQuial's Mass Communication Theory, $4^{\text {th }}$ Edition, Sage, London.

Mosco, V. (1996), The Political Economy of Communication. Rethinking and Renewal, Sage, London.

Nazarov, M.M. (2000), Mass communication in the modern world: methodology of analysis and practice of research, URSS, Moskow (in Russian).

Picard, R.G. (1989), Media Economics: Concepts and Issues, Sage Publications, London.

Picard, R. G. (2002), The Economics and Financing of Media Companies, Fordham University Press.

Rutovic, Z. (2010), „The Media Globalization - the Challenge of Qualitative Media Pluralism", Media dialogues / Medijski dijalozi, Vol. 3, No. 2, pp. 7-20.

Smythe, D. (1977), "Communications: Blindspot of Western Marxism", Canadian Journal of Political and Sociat Theory, Vol. 1, No. 3, pp. 1-27. 